Allusion was also made " to the greater certainty introduced into the classification of the older formations, which enabled equivalents to be recognized of the lower, middle and upper Cambrian of Europe, and which also showed that the older Cambrian rocks had been partially changed into gneiss and mica slate with andalusite, and that a large part of the Silurian period is represented in the Acadian provinces by volcanic rocks, quite dissimilar from the contemporaneous beds of the typical "New York Series," and more resembling the English Skiddaw and Borrowdale rocks, while they often have a very close resemblance to the older Huronian series which exists in their vicinity."

\title{
COREESPONDEINCE. \\ REPLY TO MR. USSHER AND H.E.H.
}

Sir,-I should not have troubled you with a reply to $\mathrm{Mr}$. Ussher were it not called for to prevent misunderstanding. I know nothing of the age of the clay with flints, nor of the amount of denudation which has occurred since its formation. While in Devonshire I was under the impression that the gravels capping Blackdown extended (unchanged in character) some distance down the slopes into the valleys, and that the gravels with erratics on the summit of Little Haldon extended continuously some distance downward on both sides, and, on the east side, in patches as far as the sea-coast, in a manner to me inexplicable by subaërial re-distribution. I thought these gravels might possibly represent a part of the glacial drifts of the N.W. and E. of England, and I now think it possible that the older Devonshire gravels described by Mr. Ormerod, and lately in an able paper by Mr. H. B. Woodward (Q. J. G. S. vol. xxxii.), may have been accumulated during a part of the glacial period of the N.W. and E. of England. Mr. Woodward's sections very strikingly remind one of the mode of distribution of the glacial drift of the N.W. which more or less conforms to the slopes of the valleys and hills, and which is more a wrapper than a leveller of pre-existing surface-inequalities. Of the age of these older gravels relatively to the "Head" I cannot offer an opinion, but I have little doubt that a part of the glacial period of the N.W. is represented by the "Head" described by Mr. Pengelly, which covers or rather covered (for it has been very much tampered with by man) the Miocene lignite and clay of the Bovey basin. This "Head," which contained Arctic plants, and great numbers of undoubtedly ice-borme boulders (one of them 4 feet in average diameter (1867), has undergone an amount of fluviatile and estuarine denudation extremely insignificant when compared with the excavation of the Valley of the Exe or of the pre-Miocene Bovey valley. The fact that the "Head" covers the raised beaches of the $S$.W. of England does not prove its postglacial age, because the date of these beaches relatively to those of the N.W., and indeed of the latter relatively to the glacial period or periods, is far from being certain. Mr. Godwin-Austen long ago regarded the former as, in one sense, pre-glacial. From the Land's 
End to Weston-super-Mare the raised beaches are more or less covered with "Head," which often contains large and undoubtedly ice-borne boulders. Under the raised beaches of the W. coast of Cornwall and Devon, traces of an older deposit with ice-borne boulders may occasionally be seen, as I have been informed by $\mathbf{M r}$. Whitley of Truro, who has had very extensive opportunities of observing these phenomena. The raised beaches themselves sometimes contain very far transported erratics (washed out of an older glacial deposit ?).

In answer to H. E. H., it ought to be remembered that, in Sir H. de la Beche's day, the effects of glacial action were but little understood, and it is probable that he never saw sections of curved laminæ like those which of late years have been exposed by extensive quarrying and mining operations. I would refer $H$. F. H. to the very able defence of the glacial origin of persistently curved laminæ by Mr. Tiddeman in the Q. J. G. S. vol. xxviii. p. 480.

D. MACKiNTOSH.

\section{ON THE FAUNA AND AGE OF THE SHINETON SHALES.}

SrR,-I was' glad to see in your April issue a letter by Dr. Linnarsson on the Trilobites of the Shineton Shales, as I am desirous that my conclusions should be tested in every possible way. I have carefully reviewed every detail to which he has suggested exception, and beg to submit a brief reply to his criticisms. His statements are the following.

1. Conocoryphe monile is more nearly related to Angelin's genus Euloma than to Conocoryphe striata.

To this I demur. Euloma is described by Angelin as covered with a smooth crust, and with pleurce acute, and bent back at the ends. C. monile has a granular surface and blunt pleurce. I submit that these are more important characters than the "strongly-lobed glabella and the dotted marginal furrow," in which $C$. monile is supposed to resemble Euloma. C. striata is larger than C. monile, has the glabella more conical, and with a third pair of side furrows, and has the frontal margin undotted, but on the whole the two species are of the same type.

2. Lichapyge is more closely allied to Remopleurides than to Lichas.

To this also I cannot agree. Dr. Linnarsson assumes that in my genns the "two hindermost thoracal segments" are united with the pygidium. If he were to examine my specimen, he would see that it consists of one undivided piece, and is therefore a pygidium only. This being so, it cannot be related to Remopleurides. It resembles Lichas in the number of segments (three), and in the shape of the pleuræ; but differs in the telson, which in Lichas ends in two denticles, while in Lichapyge it forms a broad sword-like blade with a central point.

3. Platypeltis is more nearly related to Niobe than to the typical Asaphi.

I myself called attention to this point on page 659 . 